\title{
STRATEGI PEMASARAN TIKET PESAWAT, PAKET WISATA PADA MASKAPAI PENERBANGAN DI MASA PANDEMI COVID-19
}

\author{
${ }^{1}$ Ryan Firdiansyah Suryawan, ${ }^{2}$ Dyah Novita \\ ${ }^{1,2}$ Sekolah Tinggi Penerbangan Aviasi, Jakarta, Indonesia \\ e-mail: ryan.firdiansyah.1979@gmail.com, dyahnovitaratnasari@gmail.com
}

\begin{abstract}
ABSTRAK
Tujuan penelitian ini membahas strategi pemasaran tiket pesawat di masa pandemi Covid19, sejak virus corona meluas hingga hampir ke seluruh dunia, para calon penumpang maskapai saling bergegas membatalkan jadwal penerbangan. Jika otoritas penerbangan tidak segera mengambil langkah yang tepat maka seluruh penerbangan di dunia diprediksi akan bangkrut pada bulan Mei mendatang, penurunan jumlah penumpang diangkut oleh Perseroan sangat terpengaruh oleh kondisi industri penerbangan yang menurun akibat Covid-19, dengan pemberlakukan PSBB di beberapa daerah terutama Ibu kota mengakibatkan masyarakat memilih untuk mengikuti peraturan pemerintah. Cash flow merupakan hal yang paling penting untuk menjaga Going Concern perusahaan. Maskapai penerbangan mempunyai dua kategori biaya yang sangat berpengaruh terhadap pengeluaran kas yaitu biaya tetap yang meliputi biaya sewa pesawat, biaya pegawai, administrasi kantor pusat dan kantor cabang dan biaya variabel penerbangan yang meliputi biaya bahan bakar, biaya kestasiunan, biaya catering, biaya navigasi dan biaya tunjangan terbang bagi awak pesawat, untuk dapat memasarkan produk atau jasa, khususnya produk tiket pesawat maka dibutuhkan Strategi promosi online yang efektif dan juga efisien yang dapat membantu calon penumpang menarik perhatian banyak konsumen. Untuk perusahaan yang sudah sukses dalam memasarkan tiket pesawat di dalam negeri, maka perusahaan juga pasti ingin dapat memasarkan tiket pesawat tersebut hingga ke luar negeri seperti ke negara-negara di benua Asia lainnya seperti Cina, Jepang, Korea, bahkan sampai negara-negara di benua Eropa seperti Belanda, Jerman, Inggris, Italia dan Prancis.
\end{abstract}

Kata Kunci : Strategi Pemasaran, Tiket Pesawat, Paket Wisata, Pandemi Covid-19. 


\section{PENDAHULUAN}

Perusahaan yang menjalankan aktivitasnya baik perusahaan yang bergerak dalam bidang jasa maupun barang mempunyai tujuan yang sama yaitu memperoleh keuntungan. Selain itu perusahaan juga ingin memberikan kepuasan atas produk yang dihasilkannya, karena kepuasan konsumen menjadi tolak ukur dari keberhasilan perusahaan dalam menghasilkan produk yang berkualitas, dan yang diinginkan oleh konsumen. Pemasaran merupakan salah satu ilmu ekonomi yang telah berkembang, dan sampai pada saat sekarang ini pemasaran sangat mempengaruhi keberhasilan suatu perusahaan untuk bisa bertahan di dalam pangsa pasar. Oleh karena itu diperlukan strategi pemasaran yang dapat memberikan pengaruh untuk menentukan berhasil atau tidaknya dalam memasarkan produknya. Apabila strategi pemasaran yang dilakukan perusahaan tersebut mampu memasarkan produknya dengan baik, hal ini akan berpengaruh terhadap tujuan perusahaan

Pemasaran (marketing) berhubungan dengan mengidentifikasi dan memenuhi kebutuhan manusia dan masyarakat. Pengertian pemasaran oleh para ahli dikemukakan berbeda-beda dalam penyajian dan penekanannya, tetapi semua itu sebenarnya mempunyai pengertian yang hampir sama antara satu dengan yang lainnya. Salah satu definisi pemasaran terpendek adalah memenuhi kebutuhan secara menguntungkan. Pertumbuhan bisnis di dunia travel dan pariwisata baik dalam maupun luar negeri menunjukkan tingginya tingkat mobilitas dari suatu daerah ke daerah yang lain. belakangan ini pertumbuhan agen-agen travel kian pesat guna mempermudah pendistribusian tiket dari suatu maskapai penerbangan tertentu untuk mempermudah pelayanan bisnis kepada pelanggan. Dengan berkembangnya teknologi dan kebutuhan akan informasi menyebabkan bertambah kompleksnya informasi yang harus bisa diolah, sehingga kebutuhan pengguna akan jaringan komputer bersama-sama semakin dipelukan. Penggunan jaringan secara bersamasama ini bertumbuh membentuk jaringan komputer yang sangat besar tersebar diseluruh belahan muka bumi yang dikenal dengan nama Internet yang bisa diakses dan dimanfaatkan untuk berbagai keperluan, oleh siapa saja, dimana saja, dan kapan saja. Ada kelebihan yang dimiliki komputer dalam proses pengolahan data terlebih dalam pengelolaan data terhadap pelayanan resevasi tiket pesawat, ini merupakan penyebab mengapa komputer dijadikan sebagai alat pengolah data. Karena sistem komputerisasi bertujuan untuk mempercepat proses yang terjadi dalam suatu sistem khususnya dalam penjualan tiket pesawat 
terbang tersebut. Reservasi online merupakan suatu sarana untuk melakukan reservasi / booking tiket pesawat terbang secara online dan realtime darimana saja dan kapan saja dan anda dapat langsung melakukan reservasi ke sistem airline.

Di samping itu dengan memanfaatkan layanan, produk customer juga mendapatkan keuntungan diharapkan dalam bisnis ini bisa saling menguntungkan bagi pihak agent travel tiket dengan customer dan bisa menjadikan suatu lapangan pekerjaan bagi masyarakat. Disini penelitian iniakan menjelaskan bagaimana membuat suatu sistem yang didalamnya terdapat proses dimana petugas dapat melayani pelanggan melalui sistem informasi dan bagaimana pelanggan yang telah menjadi member dapat melakukan booking secara langsung. Berbagai cara yang dilakukan para calon penumpang dalam melakukan pemesanan tiket, baik dengan cara memesan langsung ke maskapai penerbangan maupun kepada agen terdekat dengan lokasi calon penumpang. Namun kedua proses pemesanan tersebut kurang efektif, baik dalam segi waktu maupun biaya. Untuk itulah perlu adanya proses pemesanan untuk lebih mengefektifkan baik dalam segi waktu ataupun biaya itu sendiri serta lebih memudahkan, lebih praktis dan lebih cepat tentunya dalam melakukan pemesanan tiket. Adalah dengan menggunakan internet, karena dengan adanya fasilitas baru dengan menggunakan internet ini segala bentuk pemesanan dapat dilakukan kapan dan dimana saja sehingga lebih memudahkan masyarakat yang akan melakukan pemesanan tiket. Selain itu, dengan adanya pemesanan tiket secara online ini, setiap orang dapat mengakses untuk mendapatkan berbagai informasi baik itu informasi mengenai pesawatnya, jadwal penerbangan sampai harga yang di tawarkannya, semuanya dapat diakses dan didapatkan secara mudah.

\section{LANDASAN TEORI}

Service Science adalah Interaksi kita dengan berbagai sistem layanan (service system) sudah menjadi bagian tak terpisahkan dari kegiatan sehari-hari.Kepuasan kita terhadap hasil interaksi jasa/layanan tidak lagi hanya berorientasi pada produk layanan yang dihasilkan oleh sistem, tetapi yang lebih penting adalah tanggapan terhadap kualitas layanan yang diterima. Service science adalah disiplin ilmu baru yang menjadi penting dan makin berkembang sehingga suatu interaksi dapat menghasilkan nilai (value) yang lebih baik. Service Science dikembangkan untuk meningkatkan pemahaman kita tentang jasa / layanan (baik formal maupun informal), dalam terminologi entitas, interaksi, dan nilai yang dihasilkan. Dalam silabus Service Science, tujuan mempelajari ilmu tersebut diantaranya 
adalah : a. Menganalisis bagaimana nilai-nilai bagi konsumen/pelanggan dapat dikembangkan dalam produksi jasa/layanan dan pemasaran, $b$. Memahami seberapa kuat hubungan pelanggan tersebut dibangun dan dikelola, c. Menganalisis bagaimana layanan baru dapat dikembangkan dan diperkenalkan di pasar, d. Memahami peran manajemen sumber daya manusia dalam produksi jasa/layanan.

\section{Menurut T.Hani Handoko (2012)} pemasaran adalah suatu sistem keseluruhan dari kegiatan - kegiatan bisnis yang ditujukan untuk merencanakan, menentukan harga, mempromosikan dan mendistribusikan barang dan jasa yang memuaskan kebutuhan konsumen, sedangkan menurut Abdullah (2012) pemasaran dapat diartikan sebagai suatu proses sosial yang di dalamnya individu dan kelompok mendapatkan apa yang mereka butuhkan dan inginkan dengan menciptakan, menawarkan dan secara bebas mempertukarkan produk yang bernilai dengan pihak lain.

\section{Menurut Sudarman (2009) Pengertian} Tiket Pesawat Udara adalah Salah satu benda yang dapat dijadikan sebagai bukti tanda masuk adalah tiket. Tiket merupakan bentuk bukti yang sah dan berlaku apabila seseorang ingin memasuki atau mendatangi suatu tempat. Yang menjadi salah satu contoh tiket adalah tiket pesawat udara. Tiket adalah dokumen yang wajib dimiliki setiap calon penumpang sebelum menggunakan jasa transportasi tersebut, entah untuk moda transportasi udara, laut, dan darat sebagai suatu dokumen perjalanan yang dikeluarkan oleh suatu perusahaan dan maskapai penerbangan yang digunakan untuk melakukan suatu perjalanan. Blanko tiket biasanya diisi dengan identitas calon penumpang, rute perjalanan, dan jenis pelayanan yang diinginkan.

Menurut Bhaskara, dkk (2014: 101) bahwa kepuasan yang tinggi menciptakan kelekatan emosional terhadap produk tertentu, sehingga menumbuh- kan kesetiaan konsumen (customer loyality). Karena dengan kepuasan yang semakin tinggi diharapkan pelanggan akan menjadi semakin loyal, yaitu dengan terus mengkonsumsi produk yang dihasilkan oleh pengusaha (Rachmawati, 2010: 69). Dalam Hendra Teguh (2017) Dengan kemampuan menguasai suatu pasar yang ada, dapat memungkinkan suatu perusahaan memperoleh dana untuk membiayai kegiatan operasinya, pengembangan dan faktor lainnya. Untuk hal itu, perusahaan harus melakukan suatu konsolidasi yang mengarah ke dalam maupun keluar agar dapat mengetahui kelemahan, kekuatan, peluang serta hambatan yang mungkin diketahui apabila perusahaan dapat memutuskan tugas manajemen yang berkompetisi di pasar. Hal ini berarti merupakan suatu tugas yang harus dilakukan manajemen pemasaran. Adapun yang dimaksud 
dengan manajemen pemasaran adalah :Suatu proses perencanaan dan pelaksanaan dari perwujudan dari pemberian harga, promosi, dan distribusi dari barang-barang, jasa dan gagasan untuk menciptakan pertukaran dengan kelompok sasaran yang memenuhi tujuan pelayanan organisasi. Kalau diperhatikan kegiatan suatu manajemen pemasaran akan relatif lebih sulit dan sangat vital bagi perusahaan. Hal ini disebabkan karena pada dasarnya semua aktivitas dan prestasi perusahaan bermuara pada bidang pemasaran. Misalnya kemampuan untuk berproduksi akan ditentukan produk apa yang harus dihasilkan yang dapat diterima di pasar atau tidak. Untuk mengantisipasi hal tersebut maka bidang pemasaran berperan untuk menjembatani keinginan konsumen dan perusahaan. Hal ini berarti bidang pemasaran akan berhadapan secara langsung dengan manusia atau konsumen yang mempunyai corak serta keinginan maupun tingkah laku yang beraneka ragam. Namun apabila manajemen pemasaran mengalami kegagalan dalam mempersatukan keinginan tersebut akan menyebabkan kegagalan bagi perusahaan dalam memasarkan produk. Hal ini berartipemasaran gagal dalam usaha memperoleh dana atau uang untuk pembiayaan operasi berikutnya, pengembangan serta pembagian keuntungan yang layak bagi pemlliknya. Untuk itu kegagalan atau keberhasilan bagian pemasaran juga dipengaruhi bagian-bagian lain yang terdapat diperusahaan. Menurut Sofyan (1992): Penjulaan bukan sekedar perluasan penjualan, pemasaran meliput keseluruhan bisnis dan harus dilihat dari sudut pelanggan. Hanya pemasan dan inovasilah yang bisa menghasilkan uang, kegiatan lainnya merupakan pos biaya saja.

\section{METODE PENELITIAN}

Metode penelitian yang digunakan adalah metode penelitian kualitatif melalui studi literatur, kajian pustaka dari sudut pandang pemasaran dan menganalisa suatu kasus yang terjadi dalam beberapa pekan ini, Dalam studi tersebut akan diungkapkan strategi perusahaan penerbangan dalam meningkatkan penjualan tiket pesawat dan paket wisata di masa pandemi covid-19.

\section{PEMBAHASAN}

Secara umum, industri penerbangan merupakan salah satu industri yang menguntungkan yang ditandai dengan perubahan teknologi dan pemasaran yang cepat.Strategi pemasaran utama di dunia penerbangan dan industri penerbangan itu sendiri adalah untuk merancang sebuah produk yang secara eksplisit tidak dipikirkan oleh konsumen pada saat ini. Tantangannya tentu saja adalah untuk memprediksi ke depan apa yang diinginkan oleh konsumen, untuk meng- 
ekstrapolasi dan menyimpulkan kebutuhan pelanggan di masa depan. Sebuah maskapai penerbangan yang menerapkan prinsip-prinsip pemasaran sangat memerlukan pengetahuan mendalam tentang pasar penerbangan pada saat ini dan potensi pelayanan ke depannya. Pengetahuan ini harus mencakup pemahaman tentang bisnis di mana maskapai penerbangan tersebut berpartisipasi di dalamnya dan pengetahuan tentang teknik riset pemasaran mereka juga harus menghasilkan apa yang mereka butuhkan tentang pasar. Maskapai penerbangan harus mampu mengidentifikasi siapakah 'pelanggan' dan harus dapat membedakannya dengan 'konsumen'. Maskapai penerbangan juga harus mengetahui segmen pasarnya.Dan setelah mengetahuinya, langkah selanjutnya adalah harus mengidentifikasi dan memprioritaskan kebutuhan pelanggan di masing-masing segmen. Akhirnya, dan yang paling penting, mereka harus memeriksa pasar mereka secara dinamis, bukan statis dan dapat mengantisipasi perubahan kebutuhan pelanggan di masa depan. Tanpa riset pemasaran secara kualitatif, maskapai penerbangan tidak akan mampu untuk mencapai tujuan keseluruhan yang diinginkan oleh konsumen/pelanggan. Itulah sebabnya, tujuan utama dari perusahaan adalah untuk mempertahankan tingkat kualitas pelayanan dan mengembangkan strategi untuk meningkatkan pelayanan. Konsep layanan didasarkan pada pemahaman lingkungan yang unik di mana sebuah perusahaan tertentu beroperasi. Biasanya, maskapai penerbangan mencari strategi pemasaran tertentu dan kemudian menerjemahkannya ke dalam rencana rinci dan tindakan yang meramalkan strategi pemasaran yang efisien. Menerapkan strategi yang berorientasi kepada pelanggan lebih penting daripada teknik lainnya.Ini juga berarti harus terpatri pada seluruh sumber daya manusia pada maskapai penerbangan tersebut tentang pentingnya layanan pelanggan karena pelanggan yang puas adalah alat pemasaran yang terbaik yang tersedia sehingga citra (image) maskapai penerbangan tersebut menjadi lebih populer dan terkenal luas.Salah satu alat pemasaran terbaik yang dapat dilakukan oleh maskapai penerbangan adalah melalui pemberian sponsor (sponsorship). Beberapa maskapai penerbangan asing di dunia telah banyak yang menjadi sponsor kelas dunia di berbagai bidang. Dengan mensponsori suatu produk atau kegiatan / acara tertentu (event) akan mengangkat image maskapai penerbangan tersebut. Kerjasama antara dua pihak dalam sponsorship mempunyai tujuan yang berbeda. Pihak sponsor (maskapai penerbangan) memiliki dua tujuan utama, yaitu meningkatkan citra merek produk atau jasa dan meningkatkan kesadaran akan merek. Sedangkan pihak penerima sponsor umumnya membutuhkan dana 
segar untuk mendukung penyelanggaraan kegiatan / acara tersebut.

Sebelum masa pandemi, prioritas utama konsumen dalam memilih penerbangan bergantung aspek harga dan penjadwalan. Dengan kondisi pandemi saat ini, muncul faktor baru yang menjadi pertimbangan konsumen yakni faktor keamanan dan kenyamanan saat melakukan penerbangan. Merebaknya virus corona sampai saat ini membuat beberapa maskapai penerbangan membuat beberapa langkah untuk mengutamakan keselamatan dan kesehatan para penumpangnya, upaya meminimalkan risiko yang sedang terjadi, sebagai contoh upaya yang sudah dilakukan salah satu maskapai penerbangan telah meningkatkan kegiatan pembersihan dan disinfektan kabin dan menghentikan transit untuk penerbangan ke negara Cina. Programprogram yang sudah diterapkan ini telah memperkuat kembali pendapatan untuk maskapai penerbangan tersebut.

Pergerakan wisatawan pasca pandemi COVID-19 ini akan dimulai dari jarak yang dekat. Kecenderungan calon wisatawan dalam memilih destinasi alam (back to nature) akan menjadi pilihan utama. Namun di sisi lain, diperkirakan juga calon wisatawan akan menghindari destinasi yang sifatnya massal/keramaian. Bahkan selama vaksin belum ditemukan dan dapat diproduksi secara massal, wisatawan tetap akan menjaga jarak dan mengikuti protokol kesehatan seperti pengenaan masker saat berwisata.

Adanya pandemi global COVID-19 dan imbauan akan physical distancing ini bukan berarti membuat para pengelola destinasi wisata tidak melakukan apa-apa. Justru di masa ini, harusnya dapat menjadi momentum bagi pengelola untuk melakukan peremajaan destinasi dan peningkatan kapasitas sumber daya manusia. Selanjutnya, destinasi yang mungkin akan menjadi pilihan calon wisatawan adalah destinasi yang mampu menjamin keselamatan, kesehatan, dan kenyamanan wisatawan. Dalam hal kesehatan, tentu yang dicari adalah kebersihan dan higienitas, baik dari sisi lingkungan destinasi, akomodasi, maupun ketersediaan makanan minuman. Usaha-usaha yang dapat dilakukan antara lain perawatan dan perbaikan dari sisi destinasi, akomodasi, maupun layanan agar tampak lebih up to date dan segar. $\mathrm{Di}$ bidang kelembagaan dan sumber daya manusia, pengelola destinasi wisata dapat mengikuti pelatihan-pelatihan yang diselenggarakan secara virtual atau online. Dalam situasi tanggap darurat ini, bukan waktu yang tepat untuk melakukan promosi secara langsung (hard selling). Terlebih lagi jika memberikan diskon atau potongan harga agar masyarakat melakukan perjalanan wisata di masa pandemi 
ini. penggunaan sosial media di masa pandemi ini dapat dijadikan sebagai momentum untuk membangun komunikasi maupun meningkatkan yang baik antara pengelola destinasi dengan pengikut / calon wisatawan. Menjalin komunikasi dengan wisatawan, supplier, dan masyarakat di sekitar destinasi. Dalam hal ini pentingnya menyimpan database wisatawan yang pernah berkunjung. Database berupa nama, tempat tinggal, alamat surat elektronik (email), dan nomor telepon dapat digunakan untuk membangun komunikasi antara tuan rumah dan tamunya.

Strategi selanjutnya yang dapat dilakukan oleh pengelola destinasi wisata adalah perbaikan website. Cek kembali kualitas website dari sisi kecepatan dan kemudahan aksesnya, baik saat menggunakan perangkat selain itu, perkaya kembali paket wisata di destinasi dengan potensi-potensi yang belum diperkenalkan kepada wisatawan dan masukkan ke dalam perhitungan paket wisata yang akan disusun. Gabungkan dengan beberapa komponen seperti jasa fotografer, pemandu, kuliner, maupun akomodasi homestay di dalam paket wisata.

\section{KESIMPULAN}

Perusahan yang menjalankan aktivitasnya yang bergerak dibidang barang maupun jasa semua bertujuan untuk memperoleh laba atau keuntungan. Tolak ukur keberhasilan perusahan adalah terhadap kepuasaan para konsumen atas barang dan jasa yang di hasilkan yang mampu memenuhi kebutuhan dan keinginan konsumen. Oleh karena itu diperlukan strategi pemasaran yang dapat memberikan pengaruh untuk menentukan berhasil atau tidaknya dalam memasarkan produknya. Industri penerbangan menjadi salah satu yang terdampak paling parah akibat pandemi Corona Covid-19 yang melanda dunia, termasuk Indonesia. Tak hanya maskapai penerbangan, bisnis pengelolaan bandara juga tak bisa melarikan diri dari dampak merebaknya virus Corona Covid-19. Adanya peningkatan penularan Covid-19 di beberapa negara bagian mendorong diberlakukannya sistem lockdown secara ketat dan berulang imbasnya permintaan untuk perjalanan udara menjadi turun drastis, Dampak pandemi pada industri dalam negeri Indonesia juga cukup parah. Terkini, ratusan pesawat menganggur atau hanya parkir di bandara karena tidak ada jadwal penerbangan. Sejak 5 Februari lalu, pemerintah Indonesia memberlakukan penundaan penerbangan dari dan menuju Cina. Penundaan penerbangan juga dilakukan di banyak negara. National Emergency Crisis and Disasters Management Authority (NCEMA) dan General Civil Aviation 
Authority (GCAA) Uni Emirat Arab

(UEA) memutuskan mengurangi jumlah operasional

penerbangan.Emirates mengoperasikan 13 destinasi, dari yang sebelumnya sebanyak 159 destinasi. Bisnis penerbangan komersil maskapai Amerika Serikat (AS) juga tersengat COVID-19. United Airlines Holdings Inc dan JetBlue Airways Corp mulai memangkas penerbangan serta menerapkan kontrol biaya untuk mengatasi penurunan permintaan perjalanan. Jajaran eksekutif perusahaan tersebut mengumumkan pemotongan 10 persen penerbangan AS dan Kanada, serta memangkas 20 persen penerbangan internasional di bulan April. Total kapasitas kursi di Eropa juga telah turun 59,1 persen secara tahunan, dihitung per 23 Maret 2020. Kapasitas domestik juga berkurang 48,3 persen dan kapasitas kursi penerbangan internasional telah dipangkas 62,9 persen. Dari 20 grup maskapai penerbangan teratas di Eropa, 18 di antaranya menunjukkan pemangkasan.Bahkan pada titik tertentu, kapasitas nol bisa jadi kenyataan untuk penerbangan Eropa.

Imbauan akan physical distancing membuat para pengelola destinasi wisata dimasa COVID-19 melakukan perejamaan destinasi wisata dan meningkatkan kapasitas sumber daya manusia. Dalam hal ini destinasi mungkin menjadi pilihan calon wisatawan yang mampu menjamin keselamatan, dan kenyamanan wistawan baik dari sisi kesehatan dan kebersihan serta higienitas. Penggunaan sosial media dimasa pandemi dijadikan sebagai momentum untuk memperkaya kembali paket wisata di destinasi dengan potensi - potensi yang belum diperkenalkan kepada wisatawan sebelumnya, pengelola destinasi wisata dapat mengikuti pelatihan-pelatihan yang diselenggarakan secara virtual atau online. Salah satu strategi yang dilakukan adalah menjalin komunikasi baik antara pengelola destinasi dan calon wisatawan yang terlebih jika penggunan sosial media dijadikan promosi untuk memberikan potongan harga atau diskon agar customer tetap bisa melakukan perjalanan wisata dimasa pandemi ini.

\section{DAFTAR PUSTAKA}

Abdullah, Thamrin, dan Francis Tantri. (2012). Manajemen Pemasaran. Jakarta: PT RajaGrafindo Persada.

Assauri, Sofyan. (1992). Manajemen Pemasaran Dasar, Konsep dan Strategi, Edisi Pertama, Cetakan Ke empat, Jakarta:Rajawali.

Bashkara, Satriyo U.P., Sylivia L. Mandey, dan Olivia Nelwan. (2014). Customer Relationship Management (CRM) dan Personal Selling Pengaruhnya terhadap Kepuasan Konsumen pada 
PT Virgo Ekspres Tour \& Travel

Manado. Jurnal EMBA, Vol. 2 No. 1, 99-110.

Dharmmesta, Basu Swastha dan T. Hani Hondoko. (2012). Manajemen Pemasaran: Analisis Perilaku

Konsumen. Yogyakarta: BPFE.

Firdiansyah, Ryan, 2014. Pengaruh Kualitas Pelayanan pada Loyalitas Pelanggan yang di Mediasi Kepuasan Pelanggan. Jurnal Aliansi, Volume 9, Issue 17, Page 41, Program Pascasarjana magister Manajemen Sekolah Tinggi Manajemen IMMI - Jakarta

Kotler, Philip. (2017). Manajemen pemasaran (terjemahan Hendra Teguh dan Ronny A. Rusli AK) Edisi Revisi. Jakarta : PT. Ikrar Mandiriabadi.

Rachmawati, Rina. (2010). Pengaruh Kepuasan terhadap Loyalitas Pelanggan (Sebuah Kajian terhadap Bisnis Makanan). Jurnal Teknubuga, Volume 2 No. 2, 66-79.

Sudarman. (2009).

http://digilib.polban.ac.id/files/disk1/84/j bptppolban-gdl-sarikarmila-4197-2bab2-4.pdf 